\title{
Efektifitas Strategi Pembelajaran Analisis Nilai terhadap Pengembangan Karakter Siswa pada Mata Pelajaran Sejarah Kebudayaan Islam
}

\author{
Usep Mudani Karim Abdullah \\ Institut Agama Islam Darussalam (IAID) Ciamis, Jawa Barat. \\ Email: usep.mka@gmail.com
}

\author{
Abdul Azis \\ Program Pascasarjana, Institut Agama Islam Darussalam (IAID) Ciamis, Jawa Barat. \\ Email: abdulazis.iaid@gmail.com
}

Received: December 6, 2018 | Accepted: June 22, 2019

\begin{abstract}
This article aims to determine the differences in character between students using the value analysis learning strategy by not using the value analysis learning strategy. In value education there are various approaches, one of which is the value analysis approach. Learning strategies of value analysis in the learning of Islamic Cultural History feature stories and stories. The research method used is experimental research. The results of this study indicate that the control class that does not use the learning strategy of value analysis can be seen from the mean value (average) which is 89.04 , including the low category. Then, the experimental class that uses the learning strategy of value analysis can be seen from the mean (average) which is 112.57 including the medium category. The test results of the control class and experimental class can be seen from the value of sig. ( 2 -tailed) $0,000<0.05$, it can be concluded that the experimental testing between the control class and the experimental class was successful.
\end{abstract}

\begin{abstract}
Abstrak
Artikel ini bertujuan untuk mengetahui perbedaan karakter antara siswa menggunakan strategi pembelajaran analisis nilai dengan tidak menggunakan strategi pembelajaran analisis nilai. Dalam pendidikan nilai terdapat berbagai pendekatan, salah satunya adalah pendekatan analisis nilai. Strategi pembelajaran analisis nilai dalam pembelajaran Sejarah Kebudayaan Islam menampilkan cerita dan kisah. Metode penelitian yang digunakan adalah penelitian eksperimen. Hasil penelitian diperoleh, 1) Kelas kontrol yang tidak menggunakan strategi pembelajaran analisis nilai dapat dilihat dari nilai mean (rata-rata) yaitu 89,04 termasuk kategori rendah; 2) Kelas eksperimen yang menggunakan strategi pembelajaran analisis nilai dapat dilihat dari nilai mean (rata-rata) yaitu 112,57 termasuk kategori sedang; 3) Hasil pengujian eksperimen kelas kontrol dan kelas eksperimen dapat dilihat dari nilai sig. (2-tailed) $0,000<0,05$, maka dapat disimpulkan bahwa pengujian eksperimen antara pada kelas kontrol dan kelas eksperimen berhasil.
\end{abstract}




\section{Keywords}

Islamic education, character, learning analysis, values.

\section{Pendahuluan}

Manusia terkadang ingin diakui oleh orang lain, oleh karena itu, manusia membutuhkan pendidikan untuk menghadapi segala bentuk permasalahan dalam kehidupannya. Islam as the religion of rahmatan lil-alamin sees education as the main foundation and priority in order for someone to be prioritized and glorified (Baharun \& Ummah, 2018, pp. 21-30), Pernyataan ini senada dengan Q.S Al-Mujadalah ayat 11:

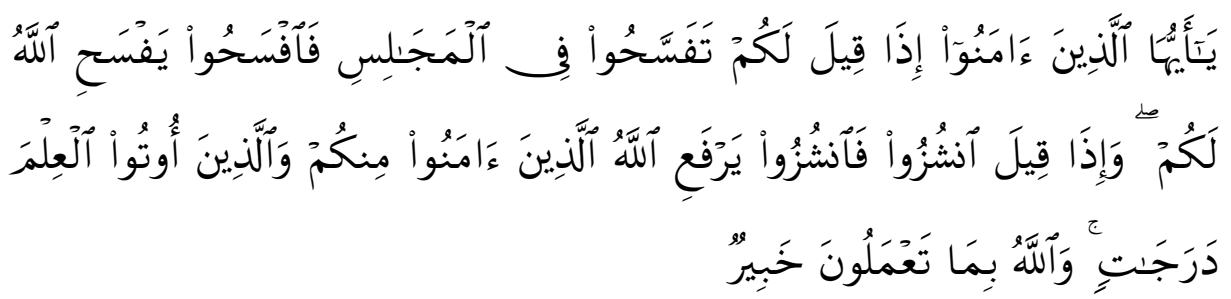

Hai orang-orang beriman apabila kamu dikatakan kepadamu: "Berlapang-lapanglah dalam majlis", Maka lapangkanlah niscaya Allah akan memberi kelapangan untukmu. dan apabila dikatakan: "Berdirilah kamu", Maka berdirilah, niscaya Allah akan meninggikan orang-orang yang beriman di antaramu dan orang-orang yang diberi ilmu pengetahuan beberapa derajat. dan Allah Maha mengetahui apa yang kamu kerjakan.

Wacana pendidikan karakter di Indonesia telah terdengar sejak tahun 2010 dalam pidato presiden pada perayaan hari pendidikan nasional pada tanggal 2 mei 2010, pendidikan karakter terus dikembangkan melalui berbagai program pendidikan baik di dalam Kementerian Pendidikan dan Kebudayaan, seperti penelitian hibah dari Pusat Penelitian Kebijakan Pendidikan, serta di dalam Kementerian Riset, Teknologi, dan Pendidikan Tinggi (Julia \& Supriyadi, 2018, p. 1). Dalam pendidikan karakter menurut Lickona menekankan pentingnya komponen pendidikan karakter yang baik, yaitu moral knowing (pengetahuan tentang moral), moral feeling (perasaan tentang moral) dan moral action (perbuatan moral). Hal ini diperlukan agar siswa mampu memahami, merasakan dan mengerjakan nilai-nilai kebajikan (ElMubarok, 2013, p. 110).

Pendidikan nilai pada pendidikan karakter terdapat berbagai pendekatan, salah satunya adalah pendekatan analisis nilai. Pendekatan analisis nilai merupakan pembelajaran yang bertujuan untuk memberikan sejumlah 
cara/teknik untuk menolong siswa berfikir logis dalam memilih nilai. Selama pelaksanaan pembelajaran, siswa mencoba memahami konsekuensi dari fakta nilai dan konflik yang terjadi diantara dua atau lebih nilai dan alasan untuk memilih nilai berdasarkan fakta yang ada (Muniarti, 2015). Menurut Driyarkara misi pendidikan nilai adalah memuncakkan domain afeksi dalam rangka memanusiakan manusia, maka cerita dan kisah yang ditampilkan mewakili kisi-kisi tentang kemanusiaan dan menjadi manusia. Oleh sebab itu, strategi pembelajaran analisis nilai dalam pembelajaran Sejarah Kebudayaan Islam di MTs N 2 Ciamis berupaya menampilkan cerita dan kisah tentang kemanusiaan dan menjadi manusia seperti menolong sesama, empati, kejujuran, saling berbagi, kesetiaan, kesejatian, hikmah, kegigihan dan keuletan, kebermanfaatan, toleransi, menghargai sesama, kesabaran, membalas kejelekan dengan kebaikan, mengedepankan kebaikan dari keburukan, bahaya kejelekan dan kualitas amal kebaikan (El-Mubarok, 2013, p. 143).

Secara sederhana, pendidikan karakter dapat didefinisikan sebagai segala usaha yang dapat dilakukan untuk mempengaruhi karakter siswa (Sudrajat, 2011, p. 49). Secara historis pendidikan karakter merupakan misi utama para Nabi. Nabi Muhammad mempunyai misi utama diutus ke muka bumi " $L i$ utammima makarim al akhlaq" yakni untuk menyempurnakan akhlak (karakter). Hal ini mengindikasikan bahwa pembentukan karakter merupakan kebutuhan utama bagi tumbuhnya cara beragama yang dapat menciptakan peradaban. Agama hadir sebagai jalan untuk menyempurnakan karakter (Rohendi, 2011, p. 3). Pendidikan karakter merupakan pendidikan nilai, budi pekerti, moral, dan watak, yang bertujuan untuk mengembangkan kemampuan siswa dalam memberikan keputusan baik dan buruk, memelihara apa yang baik, dan mewujudkan kebaikan itu dalam kehidupan sehari-hari dengan sepenuh hati (Komara, 2018, p. 24).

Prinsip pendidikan karakter meliputi: a) Mempromosikan nilai-nilai dasar etika/akhlaq mulia sebagai basis karakter; b) Mengidentifikasi karakter secara komprehensif supaya mencakup pemikiran, perasaan dan perilaku; c) Menggunakan pendekatan yang tajam, proaktif dan efektif untuk membangun karakter; d) Menciptakan komunitas sekolah yang memiliki kepedulian; e) Memberikan kesempatan kepada peserta didik untuk menunujukan perilaku yang baik; f) Memiliki cakupan terhadap kurikulim yang bermakna dan menantang yang mergai semua peserta didik, membangun karakter mereka, dan membantu mereka untuk sukses; g) Mengusahakan tumbuhnya motivasi diri pada peserta didik; h) Memfungsikan seluruh staf sekolah sebagai komunitas moral yang membagi tanggung jawab untuk pendidikan karakter dan setia pada nilai dasar yang sama; i) Adanya pembagian kepemimpinan moral dan dukungan luas dalam membangun inisiatif pendidikan karakter; j) 
Memfungsikan keluarga dan anggota masyarakat sebagai mitra dalam usaha membangun karakter; k) Mengevaluasi karakter sekolah, fungsi staf sekolah, sebagai guru-guru karakter, dan manifestasi karakter positif dalam kehidupan peserta didik (Fathurrohman, Suryana, \& Fatriany, 2017, pp. 94-95).

Fathurrohman, dkk merumuskan tujuan dari pendidikan karakter sebagai berikut: a) Mengembangkan kebiasaan dan perilaku peserta didik yang terpuji dan sejalan dengan nilai-nilai universal dan tradisi karakter bangsa yang religius; b) Mengembangkan potensi kalbu/nurani/afektif peserta didik sebagai manusia dan warganegara yang memiliki nilai-nilai karakter dan karakter bangsa; c) Menanamkan jiwa kepemimpinan dan tanggungjawab peserta didik sebagai generasi penerus bangsa; d) Mengembangkan kemampuan peserta didik menjadi manusia yang mandiri, kreatif, berwawasan kebangsaan; e) Mengembangkan lingkungan kehidupan sekolah sebagai lingkungan belajar yang aman, jujur, penuh kreativitas dan persahabatan, serta dengan rasa kebangsaan yang tinggi dan penuh kekuatan (dignity) (Fathurrohman, Suryana, \& Fatriany, 2017, pp. 97-98).

Menurut Balitbang Kementrian Pendidikan dan Kebudayaan aspek pendidikan karakter meliputi 18 nilai-nilai, yaitu: religius, jujur, toleransi, disiplin, kerja keras, kreatif, mandiri, demokratis, rasa ingin tahu, semangat kebangsaan, cinta tanah air, menghargai prestasi, bersahabat/ komunikatif, cinta damai, gemar membaca, peduli lingkungan, peduli sosial dan tanggung jawab (David, David, Resky, Rahmi, Iffa, \& Ramadhani, 2017, p. 714).

Istilah strategi (strategy) berasal dari "kata benda" dan "kata kerja" dalam bahasa Yunani. Sebagai kata benda, strategos merupakan gabungan kata stratos (militer) dengan "ago" (memimpin). Sebagai kata kerja, stratego berarti merencanakan (to plan). Strategi adalah suatu pola yang direncanakan dan ditetapkan secara sengaja untuk melakukan kegiatan atau tindakan. Strategi mencakup tujuan kegiatan, siapa yang terlibat dalam kegiatan, isi kegiatan, proses kegiatan, dan sarana penunjang kegiatan (Majid, 2014, p. 4).

Secara sederhana, istilah pembelajaran (instruction) bermakna sebagai "upaya untuk membelajarkan seseorang atau kelompok orang melalui berbagai upaya (effort) dan berbagai strategi, metode dan pendekatan ke arah pencapaian tujuan yang telah direncanakan". Pembelajaran dapat pula dipandang sebagai kegiatan guru secara terprogram dalam desain instruksional untuk membuat siswa belajar secara aktif yang menekankan pada penyediaan sumber belajar (Majid, 2014, p. 3). Pada prinsipnya, pembelajaran tidak hanya terbatas pada even-even yang di lakukan oleh guru, tetapi mencakup semua events yang mempunyai pengaruh langsung pada proses belajar yang meliputi kejadiankejadian yang di turunkan dari bahan-bahan cetak, gambar, program radio, televisi, film, slide, maupun kombinasi dari bahan-bahan tersebut. 
Pendekatan analisis nilai (value analysis approach) memberikan penekanan pada perkembangan kemampuan siswa untuk berfikir logis, dengan cara menganalisis masalah yang berhubungan dengan nilai-nilai sosial. Jika dibandingkan dengan pendekatan perkembangan kognitif, salah satu perbedaan penting antara keduanya bahwa pendekatan analisis nilai lebih menekankan pada pembahasan masalah-masalah yang memuat nilai-nilai sosial. Adapun pendekatan perkembangan kognitif memberi penekanan pada dilema moral yang bersifat perseorangan (El-Mubarok, 2013, p. 68).

Tujuan utama pendidikan nilai menurut pendekatan ini. Pertama, membantu siswa menggunakan kemampuan berpikir logis dan penemuan ilmiah dalam menganalisis masalah-masalah sosial yang berhubungan dengan nilai moral tertentu. Kedua, membantu siswa untuk menggunakan proses berpikir rasional dan analitik, dalam menghubung-hubungkan dan merumuskan konsep tentang nilai-nilai mereka. Metode-metode pengajaran yang sering digunakan adalah pembelajaran secara individu atau kelompok tentang masalah-masalah sosial yang memuat nilai moral, penyelidikan kepustakaan, penyelidikan lapangan dan diskusi kelas berdasarkan kepada pemikiran rasional (El-Mubarok, 2013, p. 68).

Pendekatan analisis nilai dalam pembelajaran memberikan penekanan pada perkembangan kemampuan siswa untuk berfikir logis dengan cara menganalisis masalah yang berhubungan dengan nilai-nilai sosial, jika dibandingkan dengan pendekatan perkembangan kognitif, salah satu perbedaan penting antara keduanya adalah pendekatan analisis nilai lebih menekankan pada pembahasan masalah yang memuat nilai-nilai sosial, adapun pendekatan perkembangan kognitif memberi penekanan pada dilema moral yang bersifat perseorangan (Muniarti, 2015, p. 204).

Pendidikan nilai dalam bingkai cerita dan kisah dilihat dari pengenalan kisah-kisah yang baik terhadap anak didik sebenarnya sangat dikenal, baik oleh orang tua maupun kalangan pendidik. Akan tetapi dalam kenyataannya, masih saja ada bolong-bolong atau bahkan terdapat keteledoran. Padahal bagaimanapun pembentukan karakter melalui tokoh-tokoh yang baik sangatlah penting.

Kisah, bagaimanapun lebih mudah untuk dipahami dibandingkan dengan wacana yang seringkali kaku dan keras untuk dicerna proses identifikasi antara seseorang dan tokoh tertentu sebenarnya bersifat alamiah karena setiap orang butuh untuk dituntun dalam mengarungi kehidupan dan menjalani dirinya sendiri. Oleh karena itulah, kisah selalu ada, diciptakan dan dinikmati. Akan tetapi tentu saja sangat mengenaskan ketika di negeri ini kisah-kisah yang layak konsumsi tidak terlalu diperhatikan dengan baik (El-Mubarok, 2013, p. 142). Karena misi pendidikan nilai adalah memuncakkan domain afeksi dalam 
rangka memanusiakan manusia, maka cerita dan kisah yang ditampilkan mewakili kisi-kisi tentang kemanusiaan dan menjadi manusia. Diantara kisikisi itu adalah menolong sesama, empati, kejujuran, saling berbagi, kesetiaan, kesejatian, hikmah, kegigihan dan keuletan, kebermanfaatan, toleransi, menghargai sesama, kesabaran, membalas kejelekan dengan kebaikan, mengedepankan kebaikan dari keburukan, bahaya kejelekan dan kualitas amal kebaikan (El-Mubarok, 2013, p. 143).

Terma "sejarah" berasal dari bahasa Arab, yaitu berasal dari kata "Syajarotun", yang artinya "pohon". Jika kita telaah secara sistematis, sejarah hampir sama dengan pohon, yaitu mempunyai cabang dan ranting, bermula dari sebuah bibit, kemudian tumbuh dan berkembang, lalu layu dan tumbang. Semakna dengan dalam bahasa Arabnya, kata sejarah dalam bahasa Indonesia berarti "silsilah", "asal-usul (keturunan)", dan "kejadian dan peristiwa yang benar-benar terjadi pada masa lampau". Diderivasi dari hal tersebut, ilmu sejarah dapat dimaknai sebagai "Pengetahuan atau uraian peristiwa dan kejadian yang benar-benar terjadi pada masa lampau" (Kusdiana, 2013, p. 1). Dalam bahasa Arab, kata "sejarah" ekuivalen dengan kata tarikh dan sirah. Secara etimologis, at-tarikh berarti ketentuan masa atau waktu. Secara terminologis, at-tarikh berarti "Sejumlah keadaan dan peristiwa yang terjadi pada masa lampau dan benarbenar terjadi pada diri individu atau masyarakat, sebagaimana yang terjadi pada kenyataan alam dan manusia". Jika pengertian tarikh tersebut disandingkan dengan kata 'Ilm, 'ilmu tarikh', dapat dimaknai sebagai "Ilmu yang membahas peristiwa atau kejadian, masa atau tempat terjadinya peristiwa, dan penyebab terjadinya peristiwa tersebut" (Kusdiana, 2013, p. 1).

Dalam penggalian sejarah terdapat beberapa metode yang dapat digunakan. Untuk menggali data yang valid berkaitan dengan sejarah, diperlukan metode penggalian sejarah yang akurat. 1) metode lisan (interview) disebut juga metode kuesioner karena terjadi suatu dialog yang dilakukan oleh pewancara (interviewer) untuk memperoleh informasi dari terwawancara (interviewee), 2) metode observasi. Dalam metode observasi, objek sejarah diamati secara langsung. 3) metode dokumenter, merupakan metode pengumpulan data yang digunakan untuk mengetahui data yang dapat dilihat secara langsung (Mas'ud, 2014, p. 7).

Sementara itu, metode penulisan sejarah mencakup sejarah Islam meliputi, 1) metode deskriptif, ditunjukkan untuk menggambar adanya peradaban islam, dengan tujuan untuk memahami yang terkandung dalam sejarah tersebut. 2) metode komparatif, merupakan metode yang berusaha membandingkan sebuah perkembangan peradaban islam dengan peradaban islam lainnya. 3) metode analisis sintesis, dilakukan dengan melihat sosok 
peradaban islam secara lebih kritis, ada analisis dan bahasan yang luas serta kesimpulan yang lebih kritis, ada analisis dan bahasan yang luas serta kesimpulan yang spesifik (Mas'ud, 2014, p. 8).

Periodisasi sejarah merupakan ciri bagi ilmu sejarah yang mengkaji peristiwa dalam konteks waktu dan tempat dengan tolok ukur yang bermacammacam. Sejarah Islam dibagi menjadi tiga periode (Yatim, 2008, p. 6), yaitu: Pertama, periode klasik (650-1250 M); merupakan kemajuan Islam dan dibagi ke dalam dua fase, yaitu fase ekspansi, integrasi, dan puncak kemajuan (6501000 M) dan fase disintegrasi (1000-1250). Kedua, periode pertengahan (1250-1800 M); dibagi ke dalam dua fase, yaitu fase kemunduran (1250-1500 M) dan fase kerajaan besar (1500-1800 M), yang dimulai dengan zaman kemajuan (1500-1700 M) dan zaman kemunduran (1700-1800 M). Ketiga, periode modern (1800 dan seterusnya); mayoritas dunia Islam berada di bawah kolonialisme dan imperialisme Eropa, serta banyak belajar dari dunia Barat dalam rangka mengembalikan balance of power. Pada masa ini pula, dunia Islam bangkit kembali dengan melakukan pembaharuan (tajdz'd) atau masa kebangkitan kembali umat Islam, serta banyak negara berpenduduk umat Islam yang mendapatkan kemerdekaannya.

\section{Metode}

Jenis penelitian yang digunakan adalah kuantitatif dengan metode eksperimen. Penelitian eksperimen merupakan suatu penelitian untuk mengetahui perubahan pada suatu keadaan yang dikendalikan secara ketat maka yang diadakan perlakuan (treatment) pada kondisi tersebut dan hal inilah yang dilakukan pada penelitian eksperimen. Penelitian eksperimen biasa dikatakan sebagai metode penelitian yang digunakan untuk mencari pengaruh perlakuan tertentu terhadap yang lain dalam kondisi yang terkendalikan.

\section{Hasil Penelitian dan Pembahasan}

Penelitian ini dilakukan dari bulan Agustus sampai bulan Oktober 2018 di Madrasah Tsanawiyah (MTs) Negeri 2 Ciamis. Jumlah siswa yang dijadikan sampel penelitian yaitu 56 siswa, kelas eksperimen (kelas VIII B) menggunakan strategi pembelajaran analisis nilai berjumlah 28 siswa dan kelas kontrol (kelas VIII C) tidak menggunakan strategi pembelajaran analisis nilai) berjumlah 28 siswa. Kegiatan penelitian dimulai dengan observasi dilanjutkan dengan wawancara kepada bapak kepala madrasah dan pembagian angket kepada masing-masing siswa, kemudian dilanjutkan dengan petunjuk pengerjaan angket tersebut, terakhir siswa mengerjakan angket. 
Penelitian terdiri dari variabel karakter dengan menggunakan strategi pembelajaran analisis nilai pada kelas eksperimen dan tidak menggunakan strategi pembelajaran analisi nilai pada kelas kontrol. Pada bagian ini dari data masing-masing variabel yang telah diolah dan dilihat dari nilai rata-rata (mean), median, modus, dan standar deviasi. Selain itu, disajikan tabel distribusi frekuensi dan diagram batang dari distribusi frekuensi masing-masing variabel. Berikut ini rincian hasil pengolahan data yang telah dilakukan dengan bantuan SPSS 20. Dari variabel kelas kontrol diperoleh melalui angket yang terdiri dari 25 item dengan jumlah responden 28 siswa. Ada 5 alternatif jawaban dimana skor tertinggi 5 dan skor terendah 1 . Skor tertinggi yaitu 125 (skor tertinggi 5 x 25 item) jika siswa menjawab dengan nilai skor tertinggi. Berdasarkan hasil penelitian dan pengolahan data.

Berdasarkan data kelas kontrol yang tidak menggunakan strategi pembelajaran analisis nilai, diperoleh skor tertinggi sebesar 115,00 dan skor terendah sebesar 76,00. Hasil analisis adalah Mean (M) sebesar 89,03, Median (Me) sebesar 85,00, Modus (Mo) sebesar 79,00, dan Standar Deviasi (SD) sebesar 11,28

Penentuan jumlah kelas interval digunakan rumus yaitu jumlah kelas = $1+3,3 \log \mathrm{n}$, dimana $\mathrm{n}$ adalah jumlah sampel atau responden. Dari perhitungan diketahui bahwa $n=28$, sehingga diperoleh banyak kelas $1+3,3 \log 28=5,77$ dibulatkan menjadi 6 kelas interval. Rentang data dihitung dengan rumus nilai maksimal - nilai minimal, sehingga diperoleh rentang data sebesar 115,00 $76,00=39$. Sedangkan panjang kelas (rentang) $/ \mathrm{K}=(39) / 6=6,5$ dibulatkan menjadi 7.

Berdasarkan tabel di atas, frekuensi variabel kelas kontrol di atas diperoleh kelas kontrol pada interval-1 sebanyak 10 siswa (35,6\%), interval ke2 sebanyak 6 siswa $(21,4 \%)$, interval ke-3 sebanyak 6 siswa $(21,4 \%)$, interval ke-4 sebanyak 2 siswa $(7,1 \%)$, interval ke-5 sebanyak 2 siswa $(7,1 \%)$, dan interval ke-6 sebanyak 2 siswa $(7,1 \%)$. Hal tersebut diolah kembali untuk melihat kategori rendah, sedang, tinggi, sehingga diperoleh hasil sebagai berikut.

Dari kelas kontrol diperoleh data kategori rendah sebanyak 16 siswa, kategori sedang sebanyak 8 siswa, kategori tinggi sebanyak 4 siswa. Dari variabel kelas eksperimen diperoleh melalui angket yang terdiri dari 25 item dengan jumlah responden 28 siswa. Ada 5 alternatif jawaban dimana skor tertinggi 5 dan skor terendah 1 . Skor tertinggi yaitu 125 (skor tertinggi 5 x 25 item) jika siswa menjawab dengan nilai skor tertinggi. Berdasarkan hasil penelitian dan pengolahan data. Berdasarkan data variabel kelas eksperimen hasil pengolahan di atas, diperoleh skor tertinggi sebesar 125,00 dan skor terendah sebesar 97,00. Hasil analisis adalah Mean (M) sebesar 112,57, Median 
(Me) sebesar 113,00, Modus (Mo) sebesar 113,00, dan Standar Deviasi (SD) sebesar 8,27.

Penentuan jumlah kelas interval digunakan rumus yaitu jumlah kelas = $1+3,3 \log \mathrm{n}$, dimana $\mathrm{n}$ adalah jumlah sampel atau responden. Dari perhitungan diketahui bahwa $\mathrm{n}=28$, sehingga diperoleh banyak kelas $1+3,3 \log 28=5,77$ dibulatkan menjadi 6 kelas interval. Rentang data dihitung dengan rumus nilai maksimal - nilai minimal, sehingga diperoleh rentang data sebesar 125,00 $97,00=28$. Sedangkan panjang kelas (rentang) $/ \mathrm{K}=(28) / 6=4,7$ dibulatkan menjadi 5

Berdasarkan tabel di atas, frekuensi variabel kelas kontrol di atas diperoleh interval-1 sebanyak 3 siswa (10,8\%), interval ke-2 sebanyak 3 siswa $(10,8 \%)$, interval ke-3 sebanyak 5 siswa (17,9\%), interval ke-4 sebanyak 7 siswa (25\%), interval ke-5 sebanyak 4 siswa (14,3\%), dan interval ke-6 sebanyak 6 siswa $(21,4)$. Hal tersebut diolah kembali untuk melihat kategori rendah, sedang, tinggi.

Pengujian prasyarat analisis dilakukan sebelum melakukan analisis data. Prasyarat yang digunakan dalam penelitian ini adalah uji normalitas dan uji homogenitas. Hasil uji prasyarat analisis disajikan sebagai berikut: Normalitas pada penelitian ini dilakukan untuk mengetahui apakah semua variabel penelitian berdistribusi normal atau tidak. Normalitas diujikan pada masingmasing variabel penelitian yang meliputi kelas eksperimen dan kelas kontrol.

Pengujian normalitas menggunakan teknik analisis Kolmogorov-Smirnov dan untuk perhitungannya menggunakan program SPSS 20,00 for windows. Data dilakukan berdistribusi normal apabila nilai signifikansi lebih besar dari 0,05 pada taraf signifikansi $\alpha=0,05$. Hasil normalitas menunjukkan bahwa variabel penelitian kelas kontrol mempunyai nilai signifikansi kurang dari 0,05 pada $(\operatorname{sign}<0,05)$, yaitu sebesar 0,027 . Oleh karena itu dapat disimpulkan bahwa data penelitian berdistribusi tidak normal. Hasil normalitas variabel penelitian kelas eksperimen mempunyai nilai signifikansi lebih besar dari 0,05 pada sign $>0,05)$, yaitu sebesar 0,200 . Oleh karena itu dapat disimpulkan bahwa data penelitian berdistribusi normal.

Uji homogenitas digunakan untuk mengetahui varian dari beberapa populasi sama atau tidak. Kriteria pengambilan keputusan: Jika sig $>0,05$ maka dikatakan bahwa varian sama dan jika sig $<0,05$ maka dikatakan bahwa varian tidak sama. Berdasarkan hasil pengujian diketahui bahwa nilai signifikasi (sig) variabel kelas kontrol dan kelas eksperimen $=0,096>0,05$ maka dapat disimpulkan bahwa variabel kelas kontrol dan kelas eksperimen mempunyai varian yang sama.

Uji Independent Sample T-test digunakan untuk mengetahui perbedaan rata-rata dua sampel yang tidak berpasangan. Uji ini sebagai syarat uji statistik 
parametrik: normal dan homogen. Dasar pengambilan keputusan adalah jika nilai sig. ( 2 tailed $<0,05$, maka terdapat perbedaan yang signifikan antara pada kelas kontrol (kelas VIII B) dan kelas eksperimen (kelas VIII C); dan jika nilai sig. (2 tailed) $>0,05$, maka tidak terdapat perbedaan yang signifikan antara pada kelas kontrol (kelas VIII B) dan kelas eksperimen (kelas VIII C). Berdasarkan hasil pengujian diketahui bahwa nilai signifikasi (sig) variabel kelas kontrol dan kelas eksperimen $=0,000<0,05$ maka dapat disimpulkan bahwa terdapat perbedaan yang signifikan antara pada kelas kontrol (kelas VIII B) dan kelas eksperimen (kelas VIII C).

Penelitian ini bertujuan untuk Mengetahui perbedaan karakter antara siswa menggunakan strategi pembelajaran analisis nilai dengan tidak menggunakan strategi pembelajaran analisis nilai. Analisis yang digunakan adalah uji t dengan bantuan SPSS for windows versi 20.00 dapat diteramgkan secara rinci sebagai berikut: Pengujian eksperimen adalah pengujian yang dilakukan untuk mengetahui akibat yang ditimbulkan dari suatu perlakuan yang diberikan secara sengaja oleh peneliti. Berdasarkan hasil pengujian diketahui bahwa nilai sig. (2-tailed) $0,000<0,05$ nilai df 27 , dan $\mathrm{t}-26,132$. Melihat dari $\mathrm{T}$ tabel kalau df nya 27 bertemu dengan 0,05 maka hasilnya 1,703

Uji t kenaikan skor nilai kelas eksperimen dan kontrol bertujuan untuk mengetahui ada tidaknya perbedaan kenaikan skor karakter siswa kelas eksperimen dan kelas kontrol pada pembelajaran Sejarah Kebudayaan Islam. Berdasarkan output pengolahan data, nilai signifikasi untuk kelas kontrol dan kelas eksperimen 0,004<0,05 sehingga dapat disimpulkan bahwa eksperimen yang telah dilakukan berhasil.

\section{Kesimpulan}

Karakter siswa pada mata pelajaran Sejarah Kebudayaan Islam yang tidak menggunakan strategi pembelajaran analisis nilai yang berjumlah 28 siswa dapat dilihat dari nilai mean (rata-rata) yaitu 89,03, sehingga mean kelas kontrol pada kategori rendah. Karakter siswa pada mata pelajaran Sejarah Kebudayaan Islam yang menggunakan strategi pembelajaran analisis nilai, berjumlah 28 siswa dapat dilihat dari nilai mean (rata-rata) yaitu 112,57, sehingga mean kelas eksperimen pada kategori sedang. Hasil pengujian eksperimen tentang karakter siswa yang menggunakan strategi pembelajaran analisis nilai dan tidak menggunakan strategi pembelajaran analisis nilai dilihat dari nilai sig. (2-tailed) $0,000<0,05$, maka dapat disimpulkan pengujian kelas control dan kelas eksperimen berhasil karena nilai sig (2 tailed) kurang dari 0,05 dan nilai $\mathrm{F}$ hitung-26,132 > 1,701 dan berada jauh antara rentang -1,701 
sampai 1,701, oleh karena itu eksperimen yang dilakukan berhasil. Artinya terdapat perbedaan karakter siswa yang menggunakan strategi pembelajaran analisis nilai dan yang tidak menggunakan strategi pembelajaran analisis nilai.

\section{DAFTAR PUSTAKA}

Baharun, H., \& Ummah, R. (2018). Strengthening Students' Character in Akhlaq Subject Through Problem Based Learning Model. Tadris: Jurnal Keguruan dan Ilmu Tarbiyah, Volume 3 Nomor 1, 21-30.

David, M., David, M., Resky, A., Rahmi, A. S., Iffa, F., \& Ramadhani, N. I. (2017). Peran Full Day School Terhadap Penanaman Karakter pada Peserta Didik Sekolah Dasar di Kota Makassar. Jurnal Pena, Volume 4 Nomor 1, 714.

El-Mubarok, Z. (2013). Membumikan Pendidikan Nilai. Bandung: Alfabeta. Fathurrohman, P., Suryana, A., \& Fatriany, F. (2017). Pengembangan pendidikan Karakter. Bandung: Refika Aditama.

Julia, \& Supriyadi, T. (2018). The Implementation of Character Education at. SHS Web of Conferences 4, 1.

Komara, E. (2018). Penguatan Pendidikan Karakter dan pembelajaran Abad 21. Sipatahoenan; South-East Asian Journal for Youth, Sports \& Health Education, Volume 4 Nomor 1, 17-26.

Kusdiana, A. (2013). Sejarah dan kebudayaan Islam. Bandung: Pustaka Setia. Majid, A. (2014). Strategi Pembelajaran. Bandung: Remaja Rosdakarya.

Mas'ud, S. (2014). Sejarah Peradaban Islam. Surabaya: UIN Sunan Ampel.

Muniarti, B. (2015). Pengaruh Pendekatan Analisis Nilai Dalam Pembelajaran IPS. Jurnal UPI.

Rohendi, E. (2011). Pendidikan Karakter di Sekolah. Eduhumaniora: Jurnal Pendidikan Dasar UPI Bandung, Volume 3 Nomor 1, 3.

Sudrajat, A. (2011). Mengapa Pendidikan Karakter? Jurnal Pendidikan Karakter, Volume 1 Nomor 1, 49.

Yatim, B. (2008). Sejarah peradaban islam. Jakarta: Raja Grafindo Persada. 
